\title{
Aid Effectiveness Agenda and the Politics of Ownership in Donor-Recipient Relationships
}

\author{
Arie Kusuma Paksi \\ International Relations \\ Universitas Muhammadiyah Yogyakarta \\ emai : ariekusumapaksi@umy.ac.id
}

\begin{abstract}
:
This article argues the political factors behind aid implementation continuously become dominant motive in donor-recipient relationships. Thus this makes the effort to effective aid which already started since post-Cold War era did not really find significant achievements. Although in the Paris meeting aid communities regards the idea of ownership as a new effort to effective aid intervention in developing countries, however, once again, the issue of power and politics remain hidden in the discussion. In fact, ownership has political dimension in which it involves power and interest among actors. In this context, each development actor is in position to win 'ownership' over development according to their agenda. Thus, this makes aid effectiveness agenda, once again, did not fully achieve much progress.
\end{abstract}

Key words: political economy, aid effectiveness, international forum, ownership

This article provides critics on the international forum on aid effectiveness agenda. It especially focuses to discuss on how various efforts to improve aid effectiveness did not really able to reach significant achievement due to dominant of political motives among actors involved in the aid relationship - even though some commitments and mechanisms have already been produced. Secondly, this discussion also provides a basis from which to critique the principle of country ownership as new effort to improve the effectiveness of foreign aid. In reality, according to political economy perspective ownership is understood as a product of political contests and so reflects a continual struggle among development actors to serve their own interests through "ownership" of development agendas (Hutchison, Hout et al. 2014). As a consequence, development directions will be "owned" by particular group of people who has power and structural opportunities rather than reflecting the interest of the whole population. Moreover, contestation between the diverse groups involved has implications for donors' ability to achieve their purposes because they must contend with local power and resources which challenge external development aid agendas.

To cover the above arguments, this 
article is divided into three sections: the first section discusses three theoretical approaches to aid for development, and argues that political economy is central to understanding donors" approaches, local ownershippolitics and development agendas. The theoretical framework is further developed in the second section, which reviews evidence regarding how the nature of political relationships among development actors has limited efforts to improve aid delivery. After reviewing the achievements of the international aid effectiveness forums in Section $C$, the fifth section focuses on the Paris Agenda on Aid Effectiveness, which identified ownership as a key to achieving better outcomes on aid delivery. The discussion explores why ownership, as a result of political processes, is a problematic concept that makes it difficult to achieve development targets because each actor is interested in promoting their own „ownership" of development and sustaining their political interests. Finally, the last section relates this discussion to lesson-learned from aid effectiveness agenda, ownership principle and the implementation of aid in TimorLeste.

\section{A. Problems of Aid Legitimacy}

This section examines political economy approaches to critically assessing international interventions and local politics. Firstly, it presents three different schools of thought in the aid and development debate and, then, focusses specifically on the political economy approach as a powerful paradigm through which to examine aid implementation, the contest of power among development actors, and how power relationships among these actors affect development policies in recipient countries.

There is a debate in the literature concerning the implications of aid: whether it is flawed but potentially useful in spurring development in the Global South, and whether it represents continuities with colonialism or even has the purpose of continuing Western domination over the countries in the Global South(Kapoor 2008, Tandon 2008). Regarding this debate, scholars can be divided into three main groups, each with characteristic approaches and strands of thought: the mainstream development aid community, sceptics and radicals. The first of these, which includes Sachs (2005) and Stiglitz (2002), argues that aid can contribute to the effort to end poverty; but only if steps are taken to improve its effectiveness. The implementation of international aid meetings, which is discussed in the next section, reflects the continuous efforts of the development aid community to improve the quality of aid delivery.

The international development aid communities understanding of aid and development has critics both from neoliberal sceptics and from more radical directions. The sceptics argue that aid tends to damage developing countries by empowering the state at the expense of the entrepreneurial poor (Easterly, 2013; Moyo, 2009). provides the example of aid 
flows in Africa. In the last several decades, Africa has received more than US\$ 1 trillion of international aid, and there is debate over the overall impact of this. Levy (1988), Gomanee, Girma et al. (2005), and Morrissey (2005) argue that aid has made positive contributions to the development of the continent, but there are many studies suggesting the opposite (e.g., Goldsmith (2001). In some cases, it is argued, aid makes the situation worse by fostering corruption, creating dependency, and causing social unrest and even civil war (Moss, Pettersson et al. 2006, Moyo 2009, Phillips 2013).

Therefore, to solve the problem of aid delivery, Easterly and Moyo argue that the world's poor do not need to borrow money from the World Bank and IMF - since the conditionality has been too soft - nor do they need to keep depending on Western aid. Rather, they suggest an extreme neoliberal approach to development as a way to gain private capital to finance development which is conducted through trade, direct foreign investment, capital markets, remittances, micro-finance and savings. This approach will impose greater discipline and force state agencies to be more efficient (Moyo 2009, Easterly 2013).

The second criticism comes from the radicals(Mosse 2005, Duffield 2007, Li 2007). This group believes relationships between countries in the Global North and Global South are exploitative rather than cooperative. According to this radical perspective, aid projects are part of neoliberal agendas that aim to facilitate capital flows to developing countries in the interests of exploiting Southern resources largely for the benefit of corporations based in the Global North. To successfully achieve these agenda, the West uses practices of domination that have been variously analysed according to two main approaches: the Foucauldian and the political economy perspectives.

The Foucauldian supporters argue aid is the practice of liberal governmentality, and constitutes a technique to make countries in the Global South accept the West's reform agendas as their own agenda(Anders 2005, Duffield 2007, Li 2007). As its name implies, this perspective uses the work of Michael Foucault on governmentality which defines as "the conduct of conduct" (Lemke 2002), meaning an effort to shape, guide or affect the conduct of a particular community by using a set of practices and calculated strategies. This can be done through several ways, including educating the people and configuring their habits and beliefs so that they will comply with the desired agenda of development (McKee 2009).

In her book, The Will to Improve: Governmentality, Development, and the Practice of Politics (2007), Li provides an example of governmentality programmes carried out by donors through implementation of integrated conservation and development projects in villages around Lore Lindu National Park in Indonesia (Li 2007).

1 ccpolitical processes often means that

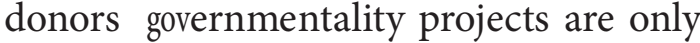
partially able to reach their neoliberal targets. 
Under the programme, these agencies identified some key problems that cause poverty and injustice and then proposed „expert" technical interventions as a way to address it without an understanding of local political context. However, since the project used the intervener"s prescription rather than being based on local problems and so failed to bring development benefits to the population excluded from the Park, it created a critical community; the highlanders became radicalized and wary of interventions that failed to deliver promised improvements.

Thus, Foucault's understanding of governmentality provides insight into how donor practices ultimately serve donor interests in line with a neoliberal agenda, by defining the problem and proposing solutions based on „superior" knowhow. However, it falls short of understanding local political practices and how development becomes the site of contestation between a variety of international and local development actors. The absence of understanding of these

Therefore, this article argues, understanding of donor intervention can better explain through structuralist political economy position, which draws upon Gramscian state theory, especially as developed by Poulantzas (1978) and Jessop (2008), which views development as a site of contestation between competing groups (with different power, resources and political opportunity structures) that have different interests and who engage in struggle over distributions of resources and the ideologies that legitimise these - development outcomes thus reflect the result of this contestation (Hughes and Hutchison 2012, Hutchison, Hout et al. 2014, Hout 2015, Hameiri, Hughes et al. 2017). From this perspective, aid flows are not simply a matter of improving standards of living. Along with the distribution of resources, they constitute never- ending social and political contestations (developed from historical political economy processes and continually changing) between different groups which compete over control of development resources producing structurally unequal societies where power and wealth are unevenly allocated (Hutchison, Hout et al. 2014, Hameiri, Hughes et al. 2017). In this view, aid programming is an intervention in this process in which it encourages local actors to struggle to influence the new form of governance which tries to build its power base through aid programmes. The final policies then reflect the balance of power between these development actors. It is this approach that underpins the theoretical understanding of power used in this article.

\section{B. The Aid Effectiveness Agenda and the Politics of Aid Delivery}

The previous section explained that a realistic understanding of the complex nature of politics in aid delivery is important to increase the effectiveness of international interventions. In this section, the framework developed above is used to evaluate the efforts of the aid community to improve the quality of aid delivery through international forums on aid effectiveness. These aimed to meet the demands of donors and recipient countries 
while producing some key agreements on aid implementation. This discussion seeks to show that these agreements did not really achieve their targets since they continuously failed to address political factors behind aid operations.

The concept of aid effectiveness has been negotiated and developed in international forums since the 1990s. It particularly emerges as critics began to point out that aid projects are often wasteful and inefficient in implementation. For this, those in the aid community camp argue, some strategies should be applied so that aid delivery quality could be improved (Sachs 2005) and (Stiglitz 2002). Thus, in order to meet the challenge presented by the sceptics, the Development Assistance Committee (DAC), an international committee with a mandate to discuss aid programmes and policies in developing countries on behalf of the Organisation for Economic Co- operation and Development (OECD) decided to promote an aid effectiveness agenda which was largely focused on increasing the quality of aid delivery in developing countries. To do this, it decided to facilitate international meetings bringing together donors and their partners. These forums are regarded as important since they addressed aid actors' differences and efforts and aims to produce specific policies for the full effectiveness of international aid in the future.

The first of the aid effectiveness forums held on 21-22 March 2002 in Monterrey, Mexico, was the Conference on Financing for Development and was attended by more than 50 Heads of State and Government. This was a response to the financial crises of the 1990s in Latin America and Asia, which slowed down and undermined the sustainability of development programmes and so contributed to the increase in poverty in affected countries - a situation that made it difficult to achieve (Millennium Development Goals) MDGs targets. As a result, at the Monterrey conference, donors committed to allocated 0.7 percent of their Gross National Income to support poor countries to reduce poverty and achieve the targets of the MDGs.

Despite these commitments, according to a UN evaluation, while there have been some successes across the globe after the implementation of the MDG agendas, aid interventions still failed to significantly improve living conditions (UN 2015) . This has been demonstrated to be specifically due to MDGs having been used as a tool of global power to serve donor interests rather than truly focusing on eradicating poverty in developing countries (Amin 2006, Bond 2006). As a result, the dominant political motives that lay behind the implementation of development agendas meant that the efforts towards fulfilling the MDGs had limited success.

To reaffirm the commitment to improving aid effectiveness, a High Level Forum on Aid Effectiveness was held in Rome 2003. It was attended by leaders from the major multilateral banks, bilateral and international organizations and donor and recipient country representatives. The result of the forum was the Rome Declaration on Harmonization. The Declaration emphasizes the commitment to enhance the quality of aid delivery by strengthening the principles 
of harmonization. In Rome, the delegation committed "to harmonize the operational policies, procedures, and practices of our institutions with those of partner country systems to improve the effectiveness of development assistance" (OECD 2003). This approach has had to be adapted since it has proved ineffective because most of the international efforts in developing countries have become fragmented rather than harmonised (Annen and Moers 2012, OECD 2012, Phillips 2013). As a result, new aid modalities were introduced in the form of budget support and the Sector Wide Approach (SWAp), replacing traditional project funding and aiming to reduce transaction costs (e.g., limiting the number of individual projects) and enhance local leadership (Andersen and Therkildsen 2007).

Budget support and SWAp became popular as a new part nership-based approach to enhance the quality of aid and support sectors of development. However, the facts show that donor countries often pursue their self-interests through budget support and SWAp mechanisms (Canadian Council for International Co-operation 2005, Riddell 2007, Dann and Hammel 2013, Swedlund 2013, Cheng and Chan 2015, International Fund for Agricultural Development 2015). Thus, aid programmes largely continue to serve the goals and objectives of donors rather than local priorities. Meanwhile, in recipient countries, interest groups with political motives struggle to influence implementation of the two methods (Andersen and Therkildsen 2007, Cruz and McPake 2011, Tilley 2014).
These conditions suggest that the problem of improving the aid quality was never primarily a technical one but was basically political in nature.

The Paris High-Level Forum on Aid Effectiveness, held in March 2005, aimed to strengthen commitments to improve the quality of aid which had been made in Monterrey and Rome. The forum itself was regarded as a breakthrough in international development since it involved a wide range of voices (35 donor countries, 26 multilateral donor organisations, 56 developing countries and 14 civil society observers) (see Mawdsley, Savage et al. 2014). The forum resulted in the Paris Declaration on Aid Effectiveness which focused on two elements: First, donor countries were encouraged to give greater local ownership in aid implementation. Second, donors and partner countries committed to be more transparent in the aid efforts aiming to create mutual accountability at international and country level (Wood, Betts et al. 2011).

According to some evaluations, there has been poor progress on achieving the Paris commitment targets for improving the quality of aid delivery in many aid partner countries. Arguably, this is because power and interests still dominate relationships among donors and local leaders(Mahmud 2008, World Bank 2008, Roberts 2009, Chandy 2011, Sjöstedt 2013, Brown 2016). Even when national governments were able to establish strategic plans, the decision to do so was decided unilaterally by a particular group of people, including local elites 
and donor agents, as a way to sustain their own development agendas, at the expense of public priorities (Brown 2016).

The third High Level Forum on the aid effectiveness agenda took place in Accra, Ghana in September 2008 and was attended by 1,200 delegations from 100 countries and intergovernmental organisations. The focus of the meeting was to evaluate, strengthen and deepen the Paris Declaration principles and commitments. This meeting took place at a time when the global context was changing significantly - in the same month that the Global Financial Crisis reached its height. Some worried that this situation might cause a drop in the amount of Western aid to developing countries. Meanwhile, at the same time the world economy was entering a commodities boom resulting from the huge increase in the power of China and the massive competition for primary commodities that this engendered. Strengthening SouthSouth Cooperation $(\mathrm{SSC})^{2}$ in the development

2 SSC refers to an alternative form of development cooperation in the context of middle income countries. In fact, the idea is not new - it was first introduced through a meeting called the AsianAfrican Conference which was held in Bandung 1955 (also known as the Bandung Conference). The Bandung conference met representatives from 29 independent nations and resulted in the creation of the Non-Alignment Movement (NAM). NAM aimed to work against the domination of the West (United States and its allies) and the East (the Soviet Union and other communist states) and to create and support SSC. At Accra, the idea of SSC was harnessed to the goal of greater aid effectiveness. agenda became one of the most highlighted points at the forum.

SSC has been regarded by some as an alternative option in international cooperation that can fulfil recipient countries development needs. However, the matter is not altogether simple. In political economy terms, the idea of „South- South" is a rhetorical device designed to invoke ideas of equality and solidarity, arising from a common colonial experience. However, analysis of the relationship between the BRICS $^{3}$ powers and the countries to which they have given development assistance shows that the promise of equality is misleading. For example, Michael Sata, the fifth President of Zambia, likened Chinese aid and investments to Trojan horses, exploiting local resources without contributing significantly to the development of African economies or society (Brautigam 2009). Thus, SSC still involves politics and interests rather than mutual cooperation.

Three years after Accra, in2011, the fourth High Level Forum, entitled Partnership on Development Cooperation, was held in Busan, South Korea. It was initiated by the $\mathrm{G} 7+$, a group of twenty fragile and conflictaffected states attempting to reshape the terms by which aid operators work. The result of the meeting was called a New Deal for Engagement in Fragile States (OECD 2012). The principles in the New Deal agreement showed the wish for better achievement of aid

3 These are Brazil, Russia, India, China and South Africa. 
efforts in the future particularly after "lessonslearned" in the previous implementation of aid which still did not make beneficial contributions to recipient countries (Da Costa 2012). In the meantime, the emergence of the G7+ and the New Deal also reflects new power dynamics between donors

and recipients in a changing aid landscape.

The Busan New Deal agreement also demonstrated another struggle for influence by local actors over the direction of social, economic and political development in aid recipient countries. This is reflected in the principle of ownership which states that "partnerships for development can only succeed if they are led by developing countries, implementing approaches that are tailored to country-specific situations and needs" (OECD 2011, p.3). It was expected, by using local actor priorities, the full interests of many elites in the country can be easily achieved. This was, in part, because it was assumed that the involvement of civil societies in development can ensure that aid efforts work in the interests of citizens. However, they have to face donors and elites who are powerful and have interests in influencing development policy (Beausang 2012, Hughes, Hooley et al. 2014, Paffenholz 2015). For instance, the New Deal process in Mogadishu was dominated by elites and international actors (Paffenholz 2015). Also, implementing the principles of country ownership and alignment does not mean the end of donor power. Donors are still able to retain their power through capacity building, training, technical assistance, reform etc.
From the above discussion, it can be seen that aid can indeed be politically profitable to certain stakeholders. Both donors and local leaders have their own interests in the aid flow. On the donor side, aid can be used as a tool for achieving their reform agenda. Therefore, to ensure the maximum gain of their reform targets they may use various methods including privileging their own aid system standards and trespassing on local institutions" systems (Bergamaschi 2009, Paul 2013, Hudson 2015) . Meanwhile from the recipients" perspective, aid inflows are also a source of power. Rather than using aid for the purpose of improving the living conditions of the poor, power- holders tend to be more interested in implementing the aid effectively for their private interests (Dietrich 2011).

Looking at the above facts, it is understandable why many authors argue that the problem of power and interests has meant that the principles produced by various international forums on aid effectiveness have led to the achievement of relatively few of their agreed goals (Chuhan and Bhargava 2006, Brown and Morton 2008, Wallace 2009, Chandy 2011, Dabelstein and Patton 2013, Paffenholz 2015). This understanding was expressed by Ban Ki-moon, UN Secretary General (2007-2016): “all too often, aid is driven more by politics than by need, undermining its effectiveness" (quoted in Herfkens \& Bains, 2015, p.57). This has meant that efforts to allocate resources to those who need it most have been continually unable to achieve this. The above evidence also clearly 
suggests that although it is relatively easy for aid actors to produce agreements, there are other factors beyond aid that prevent them from following the agreed principles and which they continually failed to address, namely, political interests (see also Carothers and De Gramont 2013).

\section{The Paris Declaration and the Politics of Ownership}

The idea of ownership that wasintroduced in the Paris Declaration of Aid Effectiveness has been widely regarded within the development aid community as a key ingredient for successful international aid programmes. Here, however, this belief is critiqued on the grounds that it is too confident in assuming that political leaders in recipient countries are committed to national development and that it ignores the fact that public policies are complex processes involving various interests from different actors. Different access to power and opportunities among these actors means that development ownership belongs to a particular group of people, not the rest of population.

As presented in the section above, the idea of country ownership became a key ingredient to improving the quality of aid delivery and was firstly introduced in the Paris Declaration on Aid Effectiveness in 2005. It encouraged both donor and recipient countries to play their roles in development practices by ensuring local ownership to increase the performance of aid implementation. This means donors were requested to reduce their domination and let the leaders in Southern countries „drive" development processes according to the principle of ownership, as stated in the Paris Declaration:

Partner countries commit to:

(1) Exercise leadership in developing and implementing their national development strategies through broad consultative processes; (2) Translate these national development strategies into prioritised results-oriented operational programmes as expressed in medium-term expenditure frameworks and annual budgets; (3) Take the lead in coordinating aid at all levels in conjunction with other development resources in dialogue with donors and encouraging the participation of civil society and the private sector. Meanwhile donors commit to: Respect partner country leadership and help strengthen their capacity to exercise it (DAC 2008).

According to the point above, recipient leadership has to have greater authority to lead in putting sound systems and policies in place. In reality, donor agencies still had dominant roles in preparing such reforms, making it difficult for the local government to take ownership of aid activities. For instance, to strengthen the implementation of particular policy donors may provide the lacking capacity. And technical assistance and capacity- building programmes are indeed powerful ways of inculcating certain attitudes and understanding of what development is and how it ought to be achieved; so, to achieve the development targets, donors determine which kind of capacity building is needed by recipient countries. This weakens local leadership and undermines genuine policy learning, at the same time as increasing donor 
power. Some individuals might be able to disagree with donors" preferences but this would cause the "delay the arrival of the much-needed resources" (Rakner, van de Walle, \& Mulaisho, 2001: p.587). Thus, the situation was not nearly as simple as the Declaration assumed.

A few years after they were agreed, the Paris Declaration"s objectives regarding ownership have made some progress, even though there are still serious problems in practice. As de Renzio, Whitfield, different actors (within the stateand between the state and other agents, within and between donor and civil society organizations, within and between different social, gender and age groups in society) and contested interests. Ownership reflects the continuing contest of power in which all parties who have different viewpoints and power resources seek to influence decisions and outcomes (Castel-Branco 2008, Mahmud 2008. While ownership-and Bergamaschi (2008) seeking strategies may vary between investigation found in many agents, different power and out African countries donors were still dominated decision-making and their projects were also fragmented, making it difficult for local government to coordinate aid according to their national development plan. These practices, then, have undermined policy ownership on the side of African leaders.

So, why has the principle of ownership not had significant success in achieving its goals? An answer to this question can be found in the political aspect of ownership, as suggested by the above criticisms of the Paris Declaration"s assumptions, rather than in the abstract definition of the term. Aid relationships involve power and power relations between structural positions among them will make development policies and directions reflect the power struggle among powerful actors rather than reflecting democratic solutions.

Some argue that the practice of respecting and supporting recipient governments greater ownership in economic policy, governance, and social welfare systems is a way to transfer responsibility to recipient leadership on the aid coordination efforts. In fact, as mentioned in the Paris Declaration (2005), donors were required to be "more harmonised, transparent and collectively effective [in their aid activities]" (DAC, 2008: p.6). However, this has not really been fulfilled (see Harrison and Mulley 2009), which suggests that donors" power and interests are still dominant in aid delivery practices. In addition, by using the ownership agenda, donors can also gain legitimation to distance themselves from the process and outcomes of aid-supported reforms (Fraser and Whitfield 2009). Thus, they can avoid taking responsibility for unsuccessful programme implementation by blaming the recipient domestic conditions, thus, enabling them to "save face" - while, if the development is successful, donors can claim that it because of their support.

Another author asserts that the transfer to local ownership can be understood as donors" shorthand for making recipient governments increase their development budget and thus reduce aid flows (Helleiner 2002). But this does not mean that the donor"s influence over development becomes weaker. As noted 
earlier, development agencies still retain a great deal of control over development because they have many features of power (like knowledge, ideas and politics) to achieve their development targets. In the case of Peru, for instance, although, to some extent, leadership of the country had control over resource allocation (including aid resources from donors), donors still used a „doctor knows best" approach (based on their technical expertise) to improve the functioning and quality of the healthcare system to "better" address the needs of Peruvian citizens. Consequently, donor agencies and their foreign implementing agents took a major role in fund management and programme implementation with limited ownership on the part of local leaders (Buffardi 2013).

In Rwanda and Tanzania, donors provide small amounts of money in budget support so that they can obtain a seat at the ,policy dialogue ec table. This then allows them to meet with key groups and determine which are the key reforms and policies (Swedlund 2013). However, donors" reform agendas are not always easy to achieve because of the "powers" in the local context that are also interested in influencing development design, and able to challenge donors" domination. As a consequence, local actors will always have a share of the "ownership", regardless of the level of the group. Once again, it can be seen that the commitment to ownership expressed in the Paris High Level Forum was only good in theory. In practice, as Bräutigam argues, ownership denotes "the extent to which there is a coincidence of interest and ideas between aid agencies and the political leadership regarding the design and implementation of certain programs and policies favoured by the aid agencies" (2000: p. 32).

\section{Conclusion}

This article discussed the political economy framework used to understand relationships among actors in improving aid delivery though aid effectiveness agenda and implementing ownership principle. The discussion highlighted that the political interests of relevant actors need to be considered central to understanding donorrecipient relationships in aid delivery. Both donors and local elites view aid resources as important tools for achieving their interests: on the donor side, aid can be used as a technology to change attitudes of people in developing countries so they conform to neoliberal ideals. Meanwhile, for local elites, aid flow is a source of power for supporting political interests. However, the nature of political process in the local country also affects relationships among actors and thus also shapes outcomes of aid programme implementation. This means that development policies are shared among particular groups of development actors (donors, elites and non-elite groups) with different interests and power resources. This, in turn, makes aid effectiveness effort does not reach significant outcomes while also makes national ownership agenda (as promoted by the Paris Declaration on improving aid delivery) impossible to achieve 
because it is contested and so privileges the more powerful groups in the community.

\section{References}

Amin, S. (2006). The millennium development goals: a critique from the South. Monthly Review. New York, Monthly Review.

\section{7.}

Anders, G. (2005). Good governance as technology: towards an ethnography of the Bretton Woods institutions. The aid effect: Giving and governing in international development. D. Mosse and D. Lewis. London, Pluto Press: 37-60.

Andersen, W. O. and O. Therkildsen (2007) - Harmonisation and alignment: the double-edged swords of budget support and decentralised aid administration. Copenhagen, Danish Institute for International Studies.

Annen, K. and L. Moers (2012).

Donor competition for aid impact, and aid fragmentation Washington, IMF.

Beausang, F. (2012). Globalization and the BRICs: why the BRICs will not rule the world for long. Basingstoke, Palgrave Macmillan.

Bergamaschi, I. (2009). Mali: patterns and limits of donor- driven ownership. The politics of aid: African strategies for dealing with donors. L. Whitfield. Oxford, Oxford University Press: $217-$ 245.

Bond, P. (2006). "Global governance campaigning and MDGs: from top-down to bottom-up anti- poverty work." Third World Quarterly 27(2): 339-354.

Brautigam, D. (2009). The dragon"s gift: the real story of China in Africa. Oxford, Oxford University Press.

Bräutigam, D. (2000). Aid dependence and governance. Stockholm, Almqvist and Wiksell International

Brown, S. (2016). Putting Paris into practice: foreign aid, national ownership, and donor alignment in Mali and Ghana. Tokyo, United Nations University.

Brown, S. and B. Morton (2008).

Reforming aid and development cooperation: Accra, Doha and beyond. Ottawa, North-South Institute. Buffardi, A. L. (2013). "Configuring „country ownership": patterns of donorrecipient relations." Development in practice $\mathbf{2 3}(8)$ :

977-990.

Canadian Council for International Cooperation (2005). The politics of the millennium

d e ve lop me n t g o a $1 \mathrm{~s}$ : contributing to strategies for ending poverty? A summary of the main arguments and conclusions. Ontario, Canadian Council for International Co-operation.

Carothers, T. and D. De Gramont (2013). Development aid confronts politics: the almost revolution. Washington, Carnegie Endowment.

Castel-Branco, C. N. (2008). Aid dependency and development: a question of ownership? a critical view. Mozambique, Instituto de Estudos Sociais e Económicos (IESE). 
Chandy, L. (2011). It"s complicated: the challenge of implementing the Paris Declaration on aid effectiveness. Brookings

Institution. Washington, Brookings Institution.

Cheng, I.-H. and S.-J. Chan, Eds. (2015). International education aid in developing Asia: policies and practices. Singapore, Springer.

Chuhan, P. and V. Bhargava (2006).

Development aid: key to balanced global development. Global issues for global citizens: an introduction to key development challenges. V. Bhargava. Washington, World Bank: 71-90.

Cruz, V. O. and B. McPake (2011). "Global health initiatives and aid effectiveness: insights from a Ugandan case study." Globalization and health 7(20): $1-10$.

Da Costa, H. (2012). "G7+ and the New Deal: country-led and country-owned initiatives: a perspective from TimorLeste." Journal of peacebuilding and development 7(2): 96-102.

Dabelstein, N. and M. Q. Patton(2013). "The Paris Declaration on aid effectiveness: history and significance." The Canadian Journal of Program Evaluation 27(3): 1936.

DAC (2008). The Paris Declaration on aid effectiveness and the Accra Agenda for Action. Paris, OECD.

Dann, P. and A. Hammel (2013).

The law of development cooperation: a comparative analysis of the World
Bank, the EU and Germany. Cambridge, Cambridge University Press.

de Renzio, P., et al. (2008).

"Reforming foreign aid practices: what country ownership is and what donors can do to support it." Retrieved 18 January 2018, from https://www.geg.ox.ac.uk/ sites/geg/ files/Reforming $\% 20$

Foreign $\% 20 \mathrm{Aid} \% 20 \mathrm{~PB} \% 20$ 2008.pdf.

Dietrich, S. (2011). "The politics of public health aid: why corrupt governments have incentives to implement aid effectively." World Development 39(1): 55-63.

Duffield, M. (2007). Development, security and unending war: governing the world of peoples. Cambridge, Polity Press.

Easterly, W. (2013). The tyranny

of experts: economists, dictators, and the forgotten rights of the poor. New York, Basic Books.

Fraser, A. and L. Whitfield (2009).

Understanding contemporary aid relationships. The politics of aid: African strategies for dealing with donors. L. Whitfield. New York, Oxford University Press: 74-107.

Goldsmith, A. A. (2001). "Foreign aid and statehood in Africa." International organization

55(01): 123-148.

Gomanee, K., et al. (2005). “Aid and growth in sub-Saharan

Africa: accounting for transmission mechanisms." Journal of International development 17(8): 1055-1075. 
Hameiri, S., et al. (2017).

International intervention and local politics. Cambridge, Cambridge University Press.

Harrison, G. and S. Mulley (2009).

Tanzania: a genuine case of recipient leadership in the aid system? The politics of aid: African strategies for dealing with donors. L. Whitfield. New York, Oxford University Press: 271-298.

Helleiner, G. (2002) . "Local ownership and donor performance monitoring: new aid relationships in Tanzania?" Journal of Human Development 3(2): 251-261.

Herfkens, E. and M. Bains (2015). Reaching our development goals: why does aid effectiveness $\mathrm{m}$ a $\mathrm{t} t \mathrm{e}$. Wa s h $\mathrm{i}$ n g t o n, OECD.

Hout, W. (2015). Putting political economy to use in aid policies. A governance practitioners" notebook: alternative ideas and approaches. A. Whaites, E. Gonzalez, S. Fyson and

G. Teskey. Paris, OECD: 8398.

Hudson, D. (2015). Global finance and development. London, Routledge.

Hughes, C. and J. Hutchison (2012). "Development effectiveness and the politics of commitment." Third World Quarterly 33(1): 17-36.

Hughes, J., et al. (2014). Implementing the New Deal for fragile states. Washington, Brookings Institution. Hutchison, J., et al. (2014).

Political economy and the aid industry in
Asia. London, Palgrave Macmillan.

International Fund for Agricultural Development (2015). Sector- wide approaches for agriculture and rural development. Rome, International Fund for Agricultural Development.

Jessop, B. (2008). State power: a strategicrelational approach. Cambridge, Polity Press.

Kapoor, I. (2008). The postcolonial politics of development. Abingdon, Routledge.

Lemke,T.(2002). "Foucault, governmentality, and critique." Rethinking marxism 14(3): 49-64.

Levy, V. (1988). "Aid and growth in subSaharan Africa: the recent experience." European economic review 32(9): 17771795.

Li, T. M. (2007). The will to improve: governmentality, development, and the practice of politics. Durham, Duke University Press.

Mahmud, A. S. (2008). Aid conditionality and democratic ownership. Aid effectiveness: democratic ownership and human rights world poverty. The Reality of Aid. Quezon City, The Reality of Aid: 2632.

Mawdsley, E., et al. (2014). “A „post- aid world"e? Paradigm shift in foreign aid and development cooperation at the 2011 Busan high level forum." The Geographical Journal 180(1): 27-38.

McKee, K. (2009). "Post- Foucauldian governmentality: what does it offer critical social policy analysis?" Critical 
Social Policy 29(3):

465-486.

Moss, T. J., et al. (2006) . An aid- institutions paradox? A review essay on aid dependency and state building in subSaharan Africa. London, Center for Global Development.

Mosse, D. (2005). Global governance

and the ethnography of international aid. The aid effect: Giving and governing in international development. D. Mosse and D. Lewis. London, Pluto Press: 1-36.

Moyo, D. (2009). Dead aid: why aid is not working and how there is another way for Africa. New York, Farrar, Straus and Giroux.

OECD (2003). Rome Declaration on harmonisation. Paris, OECD.

OECD (2011). Busan partnership

for effective development co- operation. 4th Hidh Level Forum on Aid Effectiveness. Busan, OECD.

OECD (2012). The architecture of development assistance. Paris, OECD.

OECD (2012) . The Busan partnership for effective development cooperation. Paris, OECD.

Paffenholz, T. (2015) . "Inclusive politics: lessons from and for the New Deal." Journal of peacebuilding and development 10(1): 84-89.

Paul, F. (2013). Rethinking foreign aid. Foreign Affairs. Tampa, The Council on Foreign Relations.

Phillips, D. A. (2013).

Development without aid: the decline of development aid and the rise of the diaspora. London, Anthem Press.

Poulantzas, N. (1978). State, power, socialism. London, Verso.

Rakner, L., et al. (2001). Zambia.

Aid and reform in Africa: lessons from ten case studies. S. Devarajan, D. Dollar and T. Holmgren. Washington, World Bank: 533-626.

Riddell, R. C. (2007). Does foreign aid really work? New York, Oxford University Press.

Roberts, R. (2009). Reflections on the Paris Declaration and aid effectiveness in Afghanistan. Kabul, Afghanistan Research and Evaluation Unit.

Sachs, J. (2005). The end of poverty: how we can make it happen in our lifetime. London, Penguin Books.

Sachs, J. D. (2005). The end of poverty: economic possibilities for our time. New York, Penguin Press.

Sjöstedt, M. (2013). “Aid effectiveness and the Paris Declaration: a mismatch between ownership and results -based management?" Public Administration and Development 33(2): 143-155.

Stiglitz, J. E. (2002). Globalization and its discontents. New York, WW Norton and Company.

Swedlund, H. J. (2013). "From donorship to ownership? Budget support and donor influence in Rwanda and Tanzania." Public Administration and Development 33(5): 357-370.

Tandon, Y. (2008). Ending aid dependence. Geneva, Fahamu and South Centre 
Geneva.

Tilley, H. (2014). The political economy of aid and accountability: the rise and fall of budget support inTanzania. Farnham, AshgatePublishing. New York, UN.

Wallace, T. (2009). "On the road to Accra, via Canada and County Kerry." Development in practice 19(6): 759-765
Wood, B., et al. (2011). The evaluation of the Paris Declaration. Paris, OECD.

World Bank (2008) Aid effectiveness: a progress report on implementing the Paris Declaration. 